\title{
Study of serum zinc level in overt and subclinical hypothyroidism - A case control study
}

\author{
Mahantesh B. Bhutal ${ }^{1}$, Sangappa V. K ${ }^{2, *}$, Shankarprasad D. S ${ }^{3}$ \\ ${ }^{1}$ Assistant Professor. ${ }^{2,3}$ Professor. Dept. of Biochemistry. S Nijalingappa Medical College, Bagalkot, Karnataka, India \\ *Corresponding Author: \\ Email: drsvkashinakunti@yahoo.co.in
}

Received: $8^{\text {th }}$ March, 2018

Accepted: $10^{\text {th }}$ April, 2018

\begin{abstract}
Introduction: Hypothyroidism is a clinical condition which is characterized by low thyroid hormone synthesis. It results in slowdown of metabolic processes and also presents with biochemical abnormalities including reduced serum zinc level.

Objectives: This study was done to estimate the serum zinc level in subclinical and overt hypothyroidism cases.

Materials and Methods: Study included 90 patients of hypothyroidism, of which 60 subclinical and 30 overt cases and 91 age sex matched healthy controls. Venous blood was used for testing serum fT3, fT4, TSH, and zinc levels. Statistical analysis was done using student ' $t$ ' test. Pearson's correlation between serum zinc and thyroid parameters was used to establish the relationship.
\end{abstract}

Results: The serum zinc levels were significantly decreased in subclinical and overt hypothyroidism cases compared to controls and it showed significant negative correlation with TSH.

Conclusion: Serum zinc level is decreased in both subclinical and overt hypothyroidism.

Keywords: fT3 (free triiodothyronine), fT4 (free tetraiodothyronine), TSH (thyroid stimulating hormone), Subclinical hypothyroidism, Overt.

\section{Introduction}

Hypothyroidism is a clinical condition characterized by low thyroid hormone secretion. It affects $2-15 \%$ of total population in India and females are more affected in comparison to men. Thyroid hormone helps in normal functioning of all the organs and plays a crucial role in cell differentiation. The clinical features vary from mild to overt disease. Altered thyroid hormone levels results in abnormal metabolic process leading to damage of various tissues and organs. $^{1-3}$ Thyroid hormone influence trace elements metabolism at several levels including excretion and transport. Zinc has an important role in thyroid metabolism which involves $\mathrm{T} 3$ binding to its receptors and is needed for formation and action of TRH. In turn thyroid function also influences zinc metabolism. In hypothyroidism, serum zinc levels are reduced due to impaired gastro intestinal absorption. ${ }^{4}$ Correlation between zinc and hypothyroidism is not clear and needs more extensive study. Hence this study was undertaken to estimate the serum zinc levels in hypothyroidism cases.

\section{Materials and Methods}

This case control study was conducted on patients attending medicine outpatient department of HSK hospital and research centre. Bagalkot, Karnataka. Ethical clearance was obtained from institution ethics committee. Informed written consent was taken from all the subjects enrolled for the study. Study involved 90 newly diagnosed hypothyroidism cases, out of which 60 subclinical and 30 overt hypothyroid cases were present. 91 age and sex matched healthy controls were considered for the study. Duration of the study was from February 2015-October 2015. Patients in the age group of 19 to 60 years of both gender were included. Patients with chronic kidney disease, old hypothyroid cases on treatment, muscular dystrophies, gout, hypertension and patient on drugs were excluded from the study. Detailed history was taken and three $\mathrm{ml}$ venous blood was obtained in plain tube. fT3, fT4, TSH were estimated by using SNIBE 1000 machine using CLIA method..$^{5-7}$ Serum zinc was measured using semiauto-analyzer Erba Chem $5 \mathrm{X}$ by Nitro - PAPS method. ${ }^{8}$

Statistics: Statistical analysis was done using student unpaired ' $t$ 'test for comparison of two groups and a 'p' value of $<0.05$ was considered statistically significant. Pearson's correlation between study variables was performed to establish the relationship.

\section{Results}

This study showed significant difference in serum levels of fT3, fT4, TSH and zinc between the study group and control group. The serum zinc levels in subclinical and overt hypothyroid cases were lower compared to controls which was statistically highly significant $(p<0.001)$. Serum zinc level showed negative correlation with TSH in hypothyroid patients.

Table 1 shows comparison of thyroid parameters between controls and hypothyroid cases which was statistically highly significant different with $p$ value $<0.001^{* *}$. Similarly table 2 shows highly statistical significant difference $\left(\mathrm{p}<0.001^{* *}\right)$ in $\mathrm{ft} 3, \mathrm{ft} 4$ and TSH 
levels between subclinical and overt hypothyroidism cases.

Table 1: Comparison of thyroid parameters in hypothyroid cases and controls (mean \pm SD)

\begin{tabular}{|l|c|c|c|}
\hline \multicolumn{1}{|c|}{ Thyroid parameters } & Cases (90) & Controls (91) & p value \\
\hline $\mathrm{fT}_{3}(\mathrm{pg} / \mathrm{ml})$ & $1.82 \pm 0.79$ & $2.33 \pm 0.53$ & $<0.001^{* *}$ \\
$(1.2-4.1)$ & & & \\
\hline $\mathrm{fT}_{4}(\mathrm{pg} / \mathrm{ml})$ & $9.39 \pm 3.40$ & $13.28 \pm 2.08$ & $<0.001^{* *}$ \\
$(8.7-17.8)$ & & & $<0.001^{* *}$ \\
\hline $\begin{array}{l}\mathrm{TSH}(\mu \mathrm{IU} / \mathrm{ml}) \\
(0.45-4.5)\end{array}$ & $42.88 \pm 34.86$ & $2.17 \pm 0.95$ & \\
\hline
\end{tabular}

Table 2: Thyroid parameters in subclinical and overt hypothyroidism cases expressed as mean \pm SD

\begin{tabular}{|l|c|c|c|}
\hline \multicolumn{1}{|c|}{$\begin{array}{c}\text { Thyroid } \\
\text { Parameters }\end{array}$} & Subclinical (61) & Overt (31) & p value \\
\hline $\mathrm{fT}_{3}(\mathrm{pg} / \mathrm{ml})$ & $2.31 \pm 0.43$ & $0.84 \pm 0.18$ & $<0.001^{* *}$ \\
$(1.2-4.1)$ & & $5.25 \pm 1.86$ & $<0.001^{* *}$ \\
\hline $\begin{array}{l}\mathrm{fT}_{4}(\mathrm{pg} / \mathrm{ml}) \\
(8.7-17.8)\end{array}$ & $11.5 \pm 1.55$ & & $<0.001^{* *}$ \\
\hline $\begin{array}{l}\mathrm{TSH}(\mu \mathrm{IU} / \mathrm{ml}) \\
(0.45-4.5)\end{array}$ & $20.95 \pm 12.07$ & $87.21 \pm 18.05$ & \\
\hline$* *$ Statistically highly significant $\mathrm{p}<0.05$ & & \\
\hline
\end{tabular}

Table 3: Zinc levels in both subclinical and overt cases

\begin{tabular}{|l|c|c|c|}
\hline \multicolumn{1}{|c|}{ Parameters } & Subclinical cases (60) & Overt cases (30) & p value \\
\hline $\begin{array}{c}\text { Serum zinc } \\
(60-110 \mu \mathrm{g} / \mathrm{dl})\end{array}$ & $80 \pm 9.86$ & $72.49 \pm 9.56$ & $<0.001^{* *}$ \\
\hline
\end{tabular}

Table 4: Comparison of biochemical parameters in all three groups

\begin{tabular}{|l|c|c|c|c|}
\hline \multicolumn{1}{|c|}{ Parameter } & Controls & $\begin{array}{c}\text { Subclinical } \\
\text { hypothyroidism }\end{array}$ & $\begin{array}{c}\text { Overt } \\
\text { hypothyroidism }\end{array}$ & "p" value \\
\hline $\begin{array}{l}\text { Serum Zinc }(\mu \mathrm{g} / \mathrm{dl}) \\
(60-110)\end{array}$ & $87.06 \pm 7.12$ & $80.0 \pm 9.86$ & $72.49 \pm 9.56$ & $<0.001^{* *}$ \\
\hline
\end{tabular}

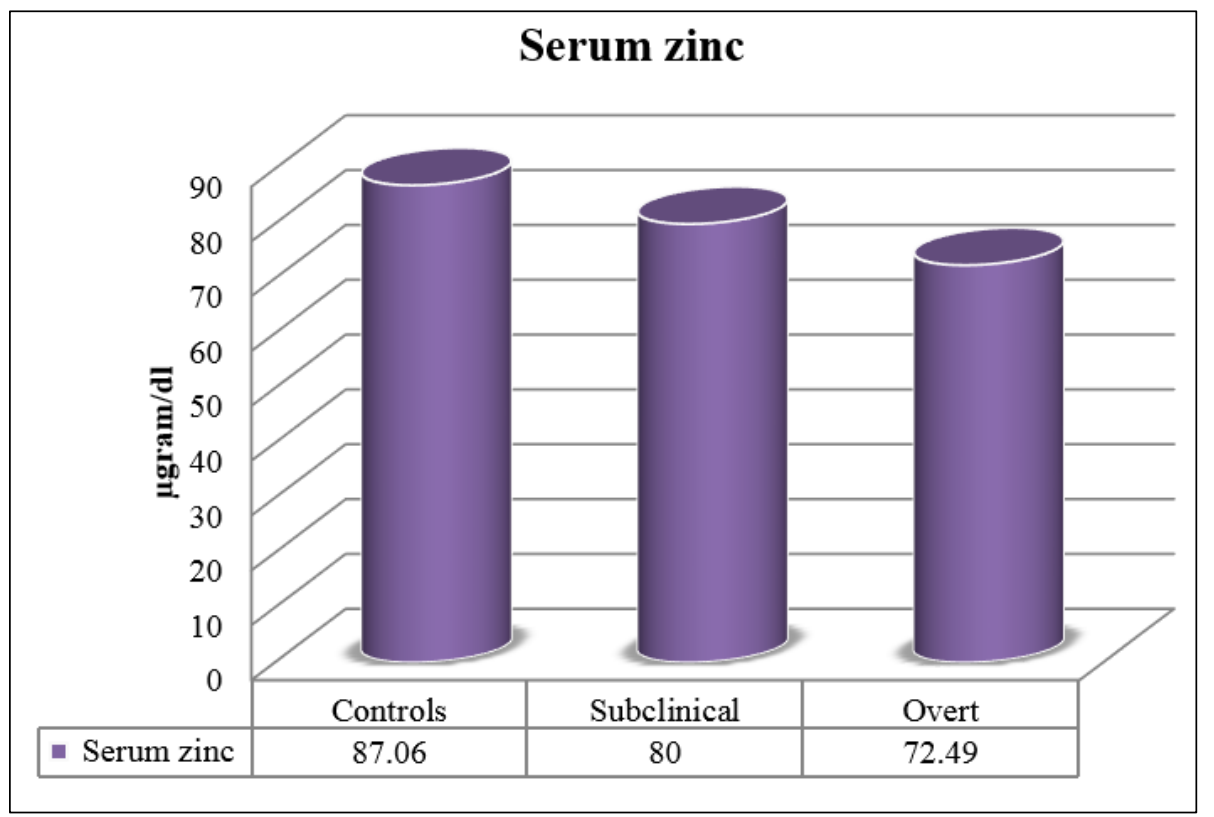

Fig. 1: 


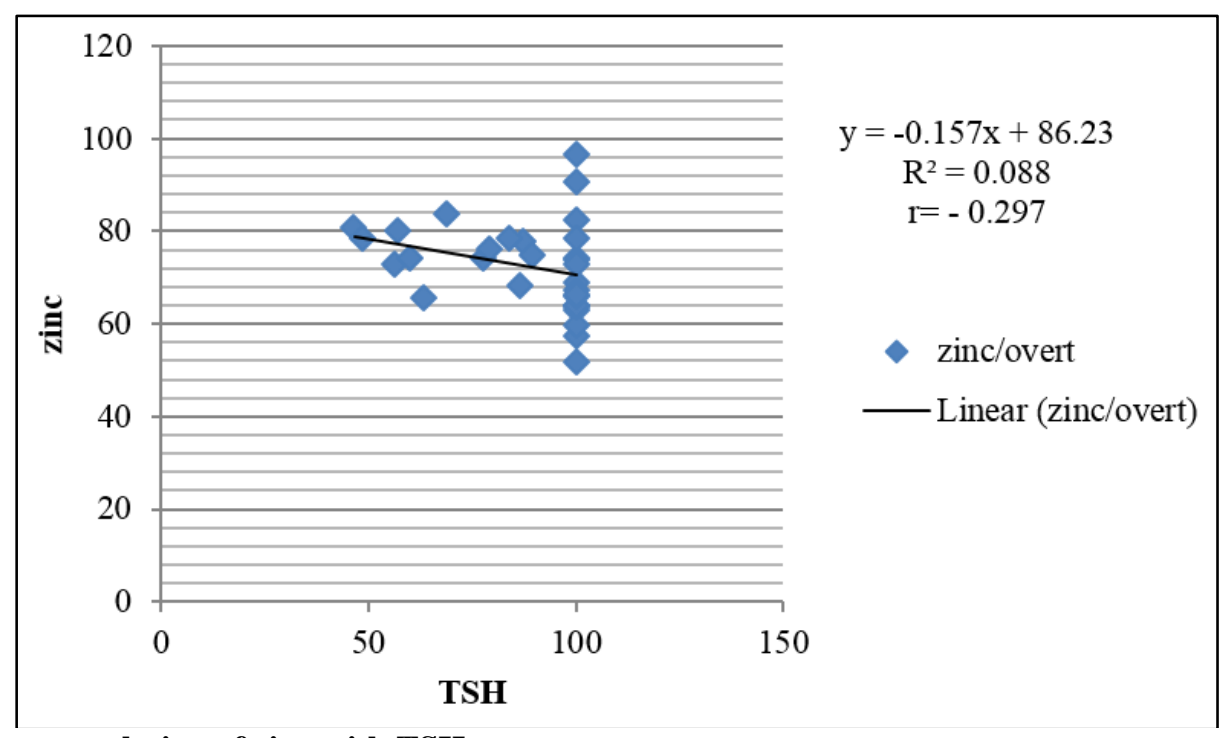

Fig. 2: Negative correlation of zinc with TSH

\section{Discussion}

Thyroid hormones influence zinc metabolism by affecting zinc absorption and excretion. Thyroid hormone binding transcription factors, which are essential for modulation of gene expression, contain zinc bound to cysteine residues. Additionally, it was reported that reduced thyroid function was strongly related to low serum zinc level. But, controversy exists regarding thyroid dysfunction and serum zinc levels as few authors report otherwise. ${ }^{9}$

In our study, we found low levels of serum zinc in the subclinical hypothyroid $(80 \pm 9.86)$ and overt hypothyroid $(72.49 \pm 9.56)$ cases compared to controls $(87.06 \pm 7.12)$ which were highly significant $\mathrm{p}<0.001 * *$.

These results are in accordance with the study done by Buchinger, ${ }^{10}$ Yoshida, ${ }^{11}$ Zhang ${ }^{12}$ who also found that there is significant decrease in the level of zinc in hypothyroidism patients in comparison to that of normal subjects. One possible explanation for these findings is that gastrointestinal absorption of zinc is severely impaired in hypothyroidism subjects. An alternative explanation would be a change in zinc distribution, the low zinc level may reflect sequestration of zinc by the liver or other tissues. Another explanation is that it is due to the significant influence of TSH in the variation of the concentration of iodine, selenium and zinc in normal and altered human thyroid tissues.

Most of the studies showed impaired gastrointestinal absorption of zinc in hypothyroid cases leading to decreased serum zinc level.

In contrast to this, study done by Sunee ${ }^{13}$ showed abnormal zinc metabolism in thyroid diseases. Hypothyroidism results in a high renal blood flow and thereby increased clearance of zinc is observed, leading to low levels of zinc values.

\section{Conclusion}

Our study showed reduced levels of serum zinc in both subclinical and overt hypothyroid cases. The causes of abnormal zinc metabolism in thyroid disease are far from fully explained. Further studies are needed to establish the clinical significance of this abnormality and the role of zinc supplementation in thyroid disease.

\section{References}

1. Rafi. Principles and Applications of Biochemistry in Medicine. Pathfinder Medical Publishers. $1^{\text {st }}$ edition 2013 April; 663-7.

2. Satyanarayana U, Chakrapani U. Biochemistry. Reed Elsevier India Private Limited. $4^{\text {th }}$ edition 2013;437-41.

3. Bello F, Bakari AG. Hypothyroidism in adults: A review and recent advances in management. Journal of diabetes and endocrinology. 2012 Nov;3(5):57-69.

4. Baloch S, Memon AR, Hayat AS, Masood N. Evaluation of serum copper and zinc in hypothyroid patients. ARPN Journal of science and technology. 2013 March;3(3):3168.

5. Kaplan MM. Assessment of Thyroid Function during Pregnancy. Thyroid, 1992;2(2):57-61.

6. Nelson JC, Wilcox RB. Analytical performance of free and total thyroxine assays. Clin Chem. 1996;42(1):14654.

7. Keffer JH. Preanalytical considerations in testing thyroid function. Clin Chem. 1996;42(1):125-34.

8. Abe Akita, Yiamashita S. Colorimetric method for the estimation of zinc. Clin Chem.1989;35(4):552-4.

9. Benerjee AK, Joshi VR, Maradi R, Mallick AK. Effect of altered levels of micronutrients on lipid parameters in thyroid dysfunction. International Journal of Applied Biology and Pharmaceutical Technology. 2011 Dec;2(4):235-39.

10. Buchinger W, Leopold B, Lind P, Langsteger W, Klima $G$, Költringer $P$, et al. Zinc sulfate following theadministration of iodine-131 on the regulation of thyroid function in rats. Hell Journal of Nuclear Medicine 1988;10(3):167-71.

11. Yoshida K, Kiso Y, Watanabe T, Kaise K, Kaise N, Itagaki M. Erythrocyte zinc in hyperthyroidism: reflection of integrated thyroid hormone levels over the previous few months. Metabolism 1990;39(2):182-186. 
12. Zhang F, Liu N, Wang X, Zhu L, and Chai Z. Study of trace elements in blood of thyroid disorder subjects before and after 131I therapy. Biological Trace Element Research. 2004;97(2):125-34.

13. Suneel B, Nagendra DR, Aparna RR, Balakrishna D, Naidu JN. Mineral Status in Thyroid Disorders.

International Journal of Biology and Pharmaceutical Technology. 2011 Oct-Dec;2(4):423-29.

How to cite this article: Bhutal MB, Sangappa VK, Shankarprasad DS. Study of serum zinc level in overt and subclinical hypothyroidism A case control study. Int $\mathbf{J}$ Clin Biochem Res. 2018;5(3):441-444. 